\title{
ע Toimintarajoitteisilla nuorilla tyydyttämätöntä tuen ja avun tarvetta koulu- ja opiskeluterveydenhuollosta
}

Kansainväliset lapsen ja vammaisten henkilöiden oikeuksia koskevat yleissopimukset velvoittavat parantamaan toimintarajoitteisten nuorten mahdollisuuksia saada palveluja yhdenvertaisesti. Tässä tutkimuksessa tarkasteltiin nuorten tuen ja avun tarvetta ja saantia terveydenhoitajalta ja lääkäriltä toimintarajoitteisilla ja muilla nuorilla sekä erityisesti tyydyttämätöntä tuen ja avun tarvetta sosiodemografisten tekijöiden mukaan. Tutkimuksessa käytettiiin valtakunnallisen Kouluterveyskyselyn 2017 aineistoa $(n=138972$ ). Aineisto analysoitiin ristiintaulukoinnilla, $\chi 2$-merkitsevyystestillä ja logistisella regressioanalyysillä. Noin 14 prosenttia nuorista arvioi, että heillä oli jokin vakava toimintarajoite eli vaikeuksia näkemisessä, kuulemisessa, liikkumisessa, muistamisessa, oppimisessa tai keskittymisessä. Nuorista, jotka ilmoittivat tarvinneensa tukea ja apua terveydenhoitajalta, kymmenesosa (10\%) ei ollut sitä saanut. Tyydyttämätön tuen ja avun tarve oli yleisempää toimintarajoitteisilla (19\%) kuin muilla (9\%) nuorilla. Lääkäriltä tukea ja apua tarvinneista nuorista noin joka kuudes (16\%) ei ollut saanut sitä. Tyydyttämätön tuen ja avun tarve oli yli kaksi kertaa yleisempää toimintarajoitteisilla nuorilla (28\%) muihin nuoriin verrattuna (13\%). Toimintarajoitteisilla nuorilla oli yli kaksinkertainen riski jäädä ilman tarvitsemaansa tukea ja apua muihin nuorïn verrattuna tarkasteltaessa sekä terveydenhoitajalta että lääkäriltä saatavaa tukea ja apua, vaikka sosiodemografiset tekijät vakioitiin. Toimintarajoitteisilla nuorilla on muita nuoria enemmän hyvinvointiin ja terveyteen liittyviä tuen tarpeita, joista osa voi jäädä tunnistamatta, ja nuori voi kokea jäävänsä ilman tukea ja apua. Erot toimintarajoitteisten ja muiden nuorten välillä ovat suuria, mikä on haaste yhdenvertaisuuden toteutumiselle. Koulu- ja opiskeluterveydenhuollolla on keskeinen rooli näiden hyvinvointierojen kaventamisessa ja yhdenvertaisuuden edistämisessä.

\section{ASIASANAT: koulu- ja opiskeluterveydenhuolto, nuoret, toimintarajoitteet, tyydyttämätön tuen ja avun tarve}

OUTI KANSTE, NINA HALME, PÄIVI SAINIO

\section{YDINASIAT}

- Toimintarajoitteisilla nuorilla on muita nuoria suurempi riski jäädä ilman tukea ja apua kouluja opiskeluterveydenhuollosta.

- Osa toimintarajoitteisten nuorten tuen ja avun tarpeista voi jäädä tunnistamatta.

- Toimintarajoitteisten ja muiden nuorten väliset erot tuen ja avun saamisessa ovat suuria - tämä on haaste yhdenvertaisuuden toteutumiselle.

- Koulu- ja opiskeluterveydenhuollolla on tärkeä tehtävä yhdenvertaisuuden edistämisessä.

\section{TOIMINTARAJOITTEISET NUORET}

Kansainväliset lapsen oikeuksia (1) ja vammaisten henkilöiden oikeuksia $(2,3)$ koskevat yleissopimukset velvoittavat varmistamaan toimintarajoitteisten lasten ja nuorten oikeuksien toteutumisen sekä parantamaan heidän mahdollisuuksiaan osallistua ja saada palveluja yhdenvertaisesti. Lähes kaikki maat, Suomi mukaan lukien, ovat ratifioineet nämä sopimukset. Vammaissopimus edellyttää tiedon kokoamista toimintarajoitteisten ihmisten tilanteesta. Tietoa tarvitaan, jotta voi- 
daan tunnistaa toimintarajoitteisten kohtaamaa eriarvoisuutta, suunnitella yhdenvertaisuuden toteutumiseksi tarvittavia toimenpiteitä ja seurata niiden vaikutuksia. (4.)

Tässä tutkimuksessa nuorten toimintarajoitteita tarkastellaan kansainvälisen suosituksen $(5,6)$ mukaan toimintakyvyn ulottuvuuksien kautta. Näitä ovat näkeminen, kuuleminen, liikkuminen, asioiden muistaminen, uusien asioiden oppiminen ja keskittyminen. Toimintakykyä koskevien kysymysten avulla voidaan tunnistaa henkilöt, joilla vaikeudet toimintakyvyn eri ulottuvuuksilla tietyissä olosuhteissa voivat rajoittaa heidän osallistumistaan yhteiskuntaan yhdenvertaisesti muiden kanssa (7).

Toimintarajoitteet ja toimintakyky voidaan ymmärtää moniulotteisena, vuorovaikutuksellisena ja dynaamisena tilana, joka koostuu terveydentilan sekä yksilön ja ympäristötekijöiden yhteisvaikutuksesta. Biopsykososiaalisessa mallissa toimintarajoitteet nähdään yksilön terveyden ja elämäntilanteen vaatimusten välisenä suhteena, johon vaikuttavat esimerkiksi saatavilla oleva tuki ja palvelut, perhe, harrastukset ja motivaatio. (8.)

Toimintarajoitteisilla nuorilla on muita nuoria useammin haasteita eri elämänalueilla. $\mathrm{Ne}$ saattavat aiheuttaa tuen ja avun tarvetta kouluja opiskeluterveydenhuollosta sekä muista palveluista. Toimintarajoitteiset lapset ja nuoret elävät muita useammin heikossa taloudellisessa tilanteessa olevissa ja vähemmistöryhmiin kuuluvissa perheissä (9-11). Toimintarajoitteisuus on yhteydessä alhaiseen koulutus- ja tulotasoon, työllisyystilanteeseen ja terveydenhuollon kustannuksiin (12). Toimintarajoitteiset nuoret kokevat terveydentilansa muita huonommaksi $(9,11,13-$ 15). Heillä on muita useammin riskikäyttäytymistä ja huonoja elintapoja (13). Toimintarajoitteiset nuoret kokevat terveyteen liittyvää eriarvoisuutta ja haasteita ylläpitää terveellisiä elintapoja. He liikkuvat muita nuoria vähemmän, ja heillä on useammin ylipainoa. (16.)

Nuoret, joilla on toimintarajoitteita, kokevat muita useammin yksinäisyyttä ja sosiaalista eristäytyneisyyttä $(9,13,14)$ sekä kärsivät mielenterveyteen liittyvistä ongelmista, kuten masennuksesta (17). Heillä on muita nuoria vähemmän mahdollisuuksia luoda sosiaalisia verkostoja ja luottamuksellisia ihmissuhteita (13). Toimintarajoitteiset nuoret kohtaavat negatiivisia asentei- ta, mikä voi johtaa kiusaamiseen, syrjintään ja sosiaaliseen eristämiseen (9). He joutuvat muita nuoria useammin fyysisen ja seksuaalisen väkivallan ja hyväksikäytön kohteiksi $(9,11,13,14)$.

\section{TYYDYTTÄMÄTÖN PALVELUTARVE}

Tyydyttämättömässä palvelutarpeessa on kysymys yksilön subjektiivisesti kokemien palvelutarpeiden ja saatujen palvelujen kohtaamattomuudesta (18). Tyydyttämätön palvelutarve liittyy palvelujen sekä tuen ja avun saatavuuteen ja saavutettavuuteen liittyviin ongelmiin. Lisäksi se kertoo palvelun sopivuudesta eli miten hyvin palvelu vastaa nuoren tarpeisiin. (18-20.) Koulu- ja opiskeluterveydenhuollon palvelut ovat kaikille perusopetuksen ja toisen asteen koulutuksen opiskelijoille tarjolla olevia universaaleja palveluja. Terveyspalvelujen käyttöä ja palveluihin pääsyä selittävän mallin mukaan yksilöön ja palvelujärjestelmään liittyvät tekijät vaikuttavat siihen saako yksilö tarvitsemiaan terveyspalveluja. Osalla on tyydyttämätöntä terveyspalvelujen tarvetta, mikä aiheuttaa eriarvoisuutta. $(21,22$.)

Sosiaali- ja terveyspalvelujen saatavuutta on usein mitattu palvelujen käytöllä, joka ei kuitenkaan huomioi mahdollisia palvelujen käyttöön liittyviä yksilöön tai palvelujärjestelmään liittyviä esteitä (23). Terveyspalvelujen saatavuuden arviointia onkin tehty sekä suomalaisessa että kansainvälisessä tutkimuksessa tarkastelemalla käytön sijasta tyydyttämätöntä palvelutarvetta, jota on kysytty asiakkaiden itse arvioimana palvelutarpeen tyydytyksenä. $(18,20,23,24$.) Tässä tutkimuksessa tyydyttämättömällä palvelutarpeella tarkoitetaan nuoren omaa arviota siitä, että hän ei ole saanut tarvitsemaansa tukea ja apua hyvinvointinsa ylläpitämiseksi terveydenhoitajalta tai lääkäriltä koulu- tai opiskeluterveydenhuollosta.

Tyydyttämätön terveyspalvelujen tarve on yhteydessä naissukupuoleen, vähemmistöryhmiin kuulumiseen, alhaiseen koulutustasoon, heikkoon tulotasoon tai taloudelliseen tilanteeseen sekä huonoksi koettuun terveydentilaan $(18,23$, 25-28). Toimintarajoitteisilla aikuisilla on muuhun aikuisväestöön verrattuna useammin tyydyttämätöntä terveyspalvelujen tarvetta $(25,29-31)$. McCollin ym. (2010) mukaan huolimatta siitä, että terveyspalvelujärjestelmä esimerkiksi Kanadassa on julkisesti rahoitettu ja periaatteessa kaikkien saatavilla, niin se ei ole pystynyt täyttä- 
mään heikoimmassa asemassa olevien, kuten toimintarajoitteisten palvelutarpeita (25). Caseyn (2015) pitkittäistutkimuksessa havaittiin toimintarajoitteiden lisääntyvän, ja samanaikaisesti tyydyttämätön terveyspalvelujen tarve kasvaa ja erityisesti toimintarajoitteisilla (29).

Yhdysvalloissa on todettu fyysisiä toimintarajoitteita kokevilla muuta aikuisväestöä huomattavasti suurempi riski tyydyttämättömään terveyspalvelujen tarpeeseen pitkällä aikajänteellä (27). Toisaalta korealaistutkimuksessa ei havaittu eroja toimintarajoitteisten ja muun väestön välillä tyydyttämättömässä terveyspalvelujen tarpeessa, vaikka esimerkiksi fyysisiä toimintarajoitteita kokevilla oli hieman muuta väestöä yleisemmin tyydyttämätöntä palvelutarvetta (26). Suomessa Mikkola ym. (2016) ovat havainneet kuulovaikeuksia kokevilla aikuisilla muita enemmän tyydyttämätöntä terveyspalvelujen tarvetta (30). Suomalaisilla aikuisilla tyydyttämätön lääkärinhoidon tarve on todettu toimintarajoitteisilla kaksinkertaiseksi muuhun väestöön verrattuna. Toimintarajoitteiset kokevat korkeat palvelumaksut lähes neljä kertaa muita useammin hoidon esteenä. (32.) Tutkimustiedon mukaan niillä, joilla on suurin terveyspalvelujen tarve, kuten toimintarajoitteisilla, on muita enemmän vaikeuksia saada tarvitsemiaan palveluja (31).

Useissa maissa on todettu, että toimintarajoitteisilla nuorilla ei ole muiden nuorten kanssa yhtäläisiä mahdollisuuksia esimerkiksi terveydenhuollon palveluihin, koulutukseen ja työhön $(9,11)$. Toimintarajoitteiset nuoret tarvitsevat muita enemmän sekä yleisiä terveyspalveluja että erityispalveluja, mutta he eivät saa tarvitsemiaan palveluja riittävästi $(9,11,13,14,33)$. Sekä Suomessa (20) että kansainvälisesti $(25-27,29)$ on kuitenkin vähän tutkimustietoa toimintarajoitteisten nuorten tyydyttämättömästä terveyspalvelujen tarpeesta. Tutkimus on kohdistunut pääosin aikuisväestöön. Palvelujärjestelmällä on tärkeä rooli nuoren hyvinvoinnin, osallisuuden ja elämänhallinnan edistäjänä sekä syrjäytymisen ehkäisemisessä (20).

Kouluissa ja oppilaitoksissa kohdataan koko nuorten ikäluokka. Kaikilla nuorilla perusopetuksessa sekä toisen asteen koulutuksessa on oikeus koulu- ja opiskeluterveydenhuollon palveluihin sekä oikeus saada tukea ja apua hyvinvointiin (34). Koulu- ja opiskeluterveydenhuoltoon kuuluvat terveydenhoitajan ja lääkärin palvelut. Tavoitteena on ylläpitää ja edistää opiskelijoiden hyvinvointia sekä koulu- ja opiskeluyhteisön hyvinvointia ja turvallisuutta. Tämä koskee myös toimintarajoitteisia lapsia ja nuoria. $(35,36$.

Tässä tutkimuksessa tarkastellaan nuorten tuen ja avun tarvetta ja saantia koulu- ja opiskeluterveydenhuollon terveydenhoitajalta ja lääkäriltä toimintarajoitteisilla ja muilla nuorilla nuorten itsensä arvioimana. Erityisesti selvitetään tyydyttämättömän tuen ja avun tarpeen yleisyyttä sekä sosiodemografisten tekijöiden yhteyttä siihen. Tutkimus tuottaa uutta tietoa toimintarajoitteisten nuorten näkemyksistä tyydyttämättömästä palvelutarpeesta koulu- ja opiskeluterveydenhuollosta huomioiden nuorten sosiodemografiset tekijät.

\section{AINEISTO JA MENETELMÄT}

\section{TUTKIMUSAINEISTON KERUU}

Tutkimus perustuu Kouluterveyskyselyn aineistoon, joka on kerätty kokonaistutkimuksena poikkileikkausasetelmalla vuonna 2017. Kouluterveyskysely on Terveyden ja hyvinvoinnin laitoksen (THL) joka toinen vuosi toteuttama koko maan laajuinen väestötutkimus, jossa saadaan tietoa nuorten hyvinvoinnista, terveydestä ja palveluista (37). Tämän tutkimuksen kohderyhmänä olivat perusopetuksen 8 . ja 9. luokkien oppilaat ( $n=116475$, vastausprosentti 63) sekä lukioiden $(\mathrm{n}=68020,51 \%)$ ja ammatillisten oppilaitosten $(\mathrm{n}=78986)$ 1. ja 2. vuoden opiskelijat. Ammatillisten oppilaitosten osalta tarkkaa vastausprosenttia ei voida luotettavasti laskea, mutta Tilastokeskuksen tietoihin perustuen arvio on $40-55$ prosenttia.

Aineistosta poistettiin niiden nuorten vastaukset $(\mathrm{n}=857 ; 0,6 \%)$, jotka ilmoittivat vakavia toimintarajoitteita kaikilla kuudella toimintakyvyn ulottuvuudella (76\% poikia, $80 \% 8$. ja 9. luokkalaisia). Tämän katsottiin olevan mahdotonta nuorella, joka pystyy vastaamaan itsenäisesti kyselylomakkeeseen. Näin pyrittiin vähentämään tuloksiin liittyvää harhaa ja lisäämään tulosten luotettavuutta (38). Tämän tutkimuksen aineisto muodostuu yhteensä 138972 nuoren vastauksista.

Nuoret vastasivat sähköiseen kyselyyn internetissä yhden oppitunnin aikana opettajan valvo- 
mana. Sähköinen lomake oli apuvälineille sopiva. Tutkimuksessa ei ole mukana kouluterveyskyselyn lyhennettyihin, selkokielisiin lomakkeisiin vastanneita, koska toimintarajoitteita mitataan erilaisilla kysymyksillä. Kyselyyn osallistuminen oli vapaaehtoista. Kysely on luottamuksellinen ja siihen vastattiin nimettömänä. (37.) Kouluterveyskyselylle on THL:n tutkimuseettisen työryhmän puoltava lausunto $(11 / 2016, \$ \$ 752)$. Tutkimus toteutettiin Tutkimuseettisen neuvottelukunnan hyvän tieteellisen käytännön periaatteiden mukaisesti (39).

\section{MITTARIT}

Toimintarajoitteen mittaamisessa nuorta pyydettiin arvioimaan neliportaisella asteikolla (ei vaikeuksia, vähän vaikeuksia, paljon vaikeuksia, en pysty lainkaan), onko hänellä vaikeuksia seuraavissa toiminnoissa: 1) nähdä, 2) kuulla, 3) kävellä puoli kilometriä, 4) muistaa asioita, 5) oppia uusia asioita tai 6) keskittyä tekemiseen, josta nauttii. Kysymyksistä muodostettiin vakavaa toimintarajoitetta kuvaava muuttuja, joka sai arvon "kyllä", jos nuorella oli "paljon vaikeuksia" tai hän "ei pystynyt lainkaan" suoriutumaan vähintään yhdellä kuudesta ulottuvuudesta. Nuorten toimintarajoitteiden tarkasteleminen perustuu kansainväliseen suositukseen toimintarajoitteiden mittaamisesta lapsilla ja nuorilla sekä väestötutkimuksissa $(5,6)$. Kysymykset kattavat kuusi ulottavuutta (esiintyvyys aineistossa \%): paljon vaikeuksia nähdä $(3,2 \%)$, kuulla $(1,3 \%)$, liikkua $(0,8 \%)$, muistaa asioita $(7,4 \%)$, oppia uusia asioita $(5,0 \%)$ ja keskittyä $(2,4 \%)$.

Tuen ja avun tarvetta mitattiin kysymyksellä "Oletko saanut tukea ja apua hyvinvointiisi seuraavilta koulun tai oppilaitoksen aikuisilta tämän lukuvuoden aikana: 1) terveydenhoitajalta ja 2) lääkäriltä”. Vastausvaihtoehdot olivat: 1) kyllä, paljon, 2) kyllä, jonkin verran, 3) en, mutta olisin tarvinnut ja 4) en ole tarvinnut apua. Vaihtoehto kolme mittaa tyydyttämätöntä tuen ja avun tarvetta. Tyydyttämätöntä tuen ja avun tarvetta tarkasteltiin koko nuorten aineistossa tukea ja apua tarvinneilla nuorilla (vastausvaihtoehtoihin 1-3 vastanneet). (20,23,34.)

Lisäksi tarkasteltiin nuorten sosiodemografisia tekijöitä, kuten sukupuolta ja kouluastetta (taulukko 1). Nuoren syntyperää tarkasteltiin neliluokkaisena muuttujana: 1) suomalainen (a. nuori ja molemmat vanhemmat syntyneet Suomessa, b. nuori syntynyt muualla tai oma syntymämaa puuttuu, molemmat vanhemmat syntyneet Suomessa, c. nuori syntynyt Suomessa ja ainoa vanhempi syntynyt Suomessa), 2) toinen vanhemmista ulkomaalaistaustainen (a. nuori syntynyt Suomessa, vanhemmista toinen syntynyt Suomessa ja toinen muualla, b. nuori syntynyt muualla, vanhemmista toinen syntynyt Suomessa, toinen muualla, c. oma syntymämaa puuttuu, vanhemmista toinen syntynyt Suomessa, toinen muualla, d. nuori syntynyt muualla, ainoa vanhempi Suomessa), 3) nuori ulkomaalaistaustainen, syntynyt Suomessa (a. nuori syntynyt Suomessa, molemmat vanhemmat syntyneet muualla, b. nuori syntynyt Suomessa, ainoa vanhempi muualla) ja 4) nuori ulkomaalaistaustainen, syntynyt ulkomailla (a. nuori syntynyt muualla, samoin molemmat vanhemmat, b. nuori syntynyt muualla, samoin ainoa vanhempi). (37.)

Äidin koulutusta tarkasteltiin kolmiluokkaisena muuttujana: 1) perusaste (peruskoulu tai vastaava), 2) keskiaste (lukio tai ammatillinen oppilaitos, lukion tai ammatillisen oppilaitoksen lisäksi ammatillisia opintoja) ja 3) korkea-aste (yliopisto, ammattikorkeakoulu tai muu korkeakoulu). Perheen koettua taloudellista tilannetta tiedusteltiin kysymyksellä "Millaiseksi arvioit perheesi taloudellisen tilanteen?". Sitä tarkasteltiin kaksiluokkaisena muuttujana: 1) erittäin tai melko hyvä ja 2) kohtalainen, melko huono tai erittäin huono. (37.)

\section{AINEISTON ANALYYSI}

Aineisto analysoitiin SPSS-tilasto-ohjelmalla (versio 25). Aineiston kuvaamisessa käytettiin prosentti- ja frekvenssijakaumia. Muuttujien välisiä yhteyksiä tarkasteltiin ristiintaulukoinnilla ja х2-merkitsevyystestillä. (40.) Logistisella regressioanalyysillä tarkasteltiin sosiodemografisten tekijöiden yhteyttä tyydyttämättömään tuen ja avun tarpeeseen. Lisäksi tarkasteltiin toimintarajoitteen yhteyttä tyydyttämättömään tuen ja avun tarpeeseen ensin vakioimattomana ja sitten vakioiden sosiodemografisilla tekijöillä (sukupuoli, kouluaste, syntyperä, äidin koulutus ja perheen koettu taloudellinen tilanne). (41.) Tilastollisen merkitsevyyden rajana käytettiin $\mathrm{p}<0,05$. 
Taulukko 1. Nuorten sosiodemografiset tekijät toimintarajoitteisilla ( $\mathrm{n}=18$ 964) ja muilla $(\mathrm{n}=113990)$ nuorilla sekä tyydyttämätön tuen ja avun tarve (ristitulosuhde, OR ja 95 prosentin luottamusvälit, LV).

\begin{tabular}{|c|c|c|c|c|c|c|c|c|}
\hline \multirow[t]{3}{*}{ Sosiodemografiset tekijät } & \multirow{2}{*}{\multicolumn{2}{|c|}{$\begin{array}{l}\text { Toimintarajoit- } \\
\text { teiset nuoret }{ }^{1}\end{array}$}} & \multirow{2}{*}{\multicolumn{2}{|c|}{$\begin{array}{c}\text { Muut nuoret } \\
\text { (ei toimintaraj.) }\end{array}$}} & \multicolumn{4}{|c|}{ Tyydyttämätön tuen ja avun tarve } \\
\hline & & & & & \multicolumn{2}{|c|}{ Terveydenhoitajalta } & \multicolumn{2}{|c|}{ Lääkäriltä } \\
\hline & $\%$ & $\mathrm{n}$ & $\%$ & $\mathrm{n}$ & OR & $95 \% \mathrm{LV}$ & OR & $95 \% \mathrm{LV}$ \\
\hline \multicolumn{9}{|l|}{ Sukupuoli } \\
\hline Poika ${ }^{2}$ & 37,0 & 6958 & 50,3 & 57069 & & & & \\
\hline Tyttö & 63,0 & 11847 & 49,7 & 56383 & 1,46 & $1,37-1,56$ & 1,73 & $1,62-1,85$ \\
\hline \multicolumn{9}{|l|}{ Kouluaste } \\
\hline Ammatillinen oppilaitos ${ }^{2}$ & 24,2 & 4581 & 22,0 & 25068 & & & & \\
\hline Lukio & 22,5 & 4260 & 26,0 & 29594 & 1,00 & $0,92-1,10$ & 1,08 & $0,98-1,18$ \\
\hline 8. ja 9. lk & 53,4 & 10123 & 52,0 & 59328 & 1,11 & $1,02-1,19$ & 1,00 & $0,93-1,08$ \\
\hline \multicolumn{9}{|l|}{ Syntyperä } \\
\hline Suomalainen ${ }^{2}$ & 83,7 & 14749 & 88,9 & 95112 & & & & \\
\hline $\begin{array}{l}\text { Toinen vanhemmista } \\
\text { ulkomaalaistaustainen }\end{array}$ & 8,7 & 1541 & 6,4 & 6830 & 1,30 & $1,16-1,45$ & 1,27 & $1,13-1,42$ \\
\hline $\begin{array}{l}\text { Ulkomaalaistaustainen } \\
\text { (syntynyt Suomessa) }\end{array}$ & 2,4 & 428 & 1,7 & 1777 & 1,14 & $0,93-1,40$ & 1,14 & $0,93-1,38$ \\
\hline $\begin{array}{l}\text { Ulkomaalaistaustainen } \\
\text { (syntynyt ulkomailla) }\end{array}$ & 5,1 & 894 & 3,1 & 3300 & 1,55 & $1,37-1,76$ & 1,42 & $1,25-1,61$ \\
\hline \multicolumn{9}{|l|}{ Äidin koulutus } \\
\hline Korkea-aste ${ }^{2}$ & 35,0 & 5940 & 41,7 & 43939 & & & & \\
\hline Keskiaste & 55,1 & 9344 & 52,7 & 55564 & 0,92 & $0,86-0,99$ & 0,99 & $0,92-1,06$ \\
\hline Perusaste & 9,9 & 1672 & 5,6 & 5868 & 1,22 & $1,09-1,37$ & 1,27 & $1,13-1,43$ \\
\hline \multicolumn{9}{|c|}{ Perheen koettu taloudellinen tilanne } \\
\hline Erittäin tai melko hyvä² & 49,8 & 8948 & 67,4 & 73983 & & & & \\
\hline Huono tai kohtalainen & 50,2 & 9030 & 32,6 & 35847 & 1,69 & $1,59-1,79$ & 1,92 & $1,80-2,04$ \\
\hline
\end{tabular}

${ }^{1}$ paljon vaikeuksia tai ei pysty lainkaan vähintään yhdellä toimintakyvyn ulottuvuudella

Toimintarajoitteisten ja muiden nuorten väliset erot tilastollisesti merkitseviä p-arvolla $<0,001$ ( $\chi 2$-merkitsevyystesti)

kaikkien sosiodemografisten tekijöiden mukaan, ${ }^{2}$ referenssiryhmä logistisissa regressiomalleissa

\section{TULOKSET}

\section{NUORTEN TAUSTATIEDOT}

Noin joka seitsemännellä $(14 \%, n=18964)$ nuorella oli jokin vakava toimintarajoite eli oman arvion mukaan vaikeuksia nähdä, kuulla, kävellä puoli kilometriä, muistaa asioita, oppia uusia asioita tai keskittyä mieluiseen tekemiseen. Toimintarajoitteisista nuorista suurempi osa oli tyttöjä kuin muista nuorista $(\mathrm{p}<0,001)$. Noin puolet vastaajista oli perusopetuksen 8 . ja 9. luokkalaisia sekä noin neljännes lukiolaisia ja ammatillisissa oppilaitoksissa opiskelevia. Toimintarajoitteisista nuorista suurempi osa kuin muista nuorista oli ammatillisissa oppilaitoksissa opiskelevia ja pienempi osa lukiolaisia $(\mathrm{p}<0,001)$.

Useampi kuin joka kymmenes nuorista tai toinen heidän vanhemmistaan oli ulkomaistaustainen, ja toimintarajoitteista nuorista suurempi osa kuin muista nuorista $(\mathrm{p}<0,001)$. Joka kymmenennellä toimintarajoitteisten nuorten äideistä oli korkeintaan perusasteen koulutus.
Kolmannes nuorista arvioi perheen taloudellisen tilanteen huonoksi tai kohtalaiseksi. Toimintarajoitteista nuorista näin arvioi suurempi osa kuin muista nuorista $(\mathrm{p}<0,001)$. (Taulukko 1.)

\section{NUORTEN TUEN JA AVUN TARVE}

Kaikista nuorista 65 prosenttia ei ollut tarvinnut tukea ja apua terveydenhoitajalta kuluneen lukuvuoden aikana. Reilu kolmannes (35\%) oli tarvinnut tukea ja apua: he olivat saaneet sitä paljon tai jonkin verran tai jääneet ilman tarpeesta huolimatta. Nuorista 78 prosenttia ei ollut tarvinnut tukea ja apua lääkäriltä, ja runsas viidennes (22\%) oli tarvinnut sitä.

Toimintarajoitteisista nuorista suurempi osa kuin muista nuorista oli tarvinnut tukea ja apua terveydenhoitajalta $(47 \%$ vs. $34 \%, \mathrm{p}<0,001)$ ja lääkäriltä $(32 \%$ vs. $21 \%, \mathrm{p}<0,001)$. Toimintarajoitteisista nuorista suurempi osa kuin muista nuorista oli myös saanut tukea ja apua sekä terveydenhoitajalta $(\mathrm{p}<0,001)$ että lääkäriltä $(\mathrm{p}<0,001)$. Kuitenkin toimintarajoitteisissa nuo- 
Taulukko 2. Nuorten tuen ja avun tarve ja saanti toimintarajoitteisilla ( $\mathrm{n}=18$ 964) ja muilla ( $\mathrm{n}=113$ 990) nuorilla.

\begin{tabular}{|c|c|c|c|c|c|c|}
\hline \multirow[t]{2}{*}{ Tuen ja avun saanti } & \multicolumn{2}{|c|}{$\begin{array}{c}\text { Toimintarajoitteiset } \\
\text { nuoret }{ }^{1}\end{array}$} & \multicolumn{2}{|c|}{$\begin{array}{c}\text { Muut nuoret } \\
\text { (ei toimintaraj.) }\end{array}$} & \multicolumn{2}{|c|}{$\begin{array}{c}\text { Kaikki nuoret } \\
\text { yhteensä }\end{array}$} \\
\hline & $\%$ & $\mathrm{n}$ & $\%$ & $\mathrm{n}$ & $\%$ & $\mathrm{n}$ \\
\hline \multicolumn{7}{|l|}{ Terveydenhoitajalta } \\
\hline Kyllä, paljon & 10,5 & 1837 & 8,7 & 9266 & 8,9 & 11103 \\
\hline Kyllä, jonkin verran & 27,6 & 4800 & 22,1 & 23655 & 22,9 & 28455 \\
\hline Ei, mutta olisi tarvinnut & 8,7 & 1518 & 2,9 & 3089 & 3,7 & 4607 \\
\hline Ei ole tarvinnut apua & 53,2 & 9265 & 66,3 & 71095 & 64,5 & 80360 \\
\hline \multicolumn{7}{|l|}{ Lääkäriltä } \\
\hline Kyllä, paljon & 6,7 & 1159 & 5,6 & 5943 & 5,7 & 7102 \\
\hline Kyllä, jonkin verran & 16,2 & 2810 & 12,5 & 13359 & 13,1 & 16169 \\
\hline Ei, mutta olisi tarvinnut & 8,9 & 1534 & 2,8 & 2981 & 3,6 & 4515 \\
\hline Ei ole tarvinnut apua & 68,2 & 11801 & 79,1 & 84232 & 77,6 & 96033 \\
\hline
\end{tabular}

${ }^{1}$ paljon vaikeuksia tai ei pysty lainkaan vähintään yhdellä toimintakyvyn ulottuvuudella

Toimintarajoitteisten ja muiden nuorten väliset erot tilastollisesti merkitseviä p-arvolla $<0,001$ ( $\chi 2$-merkitsevyystesti)

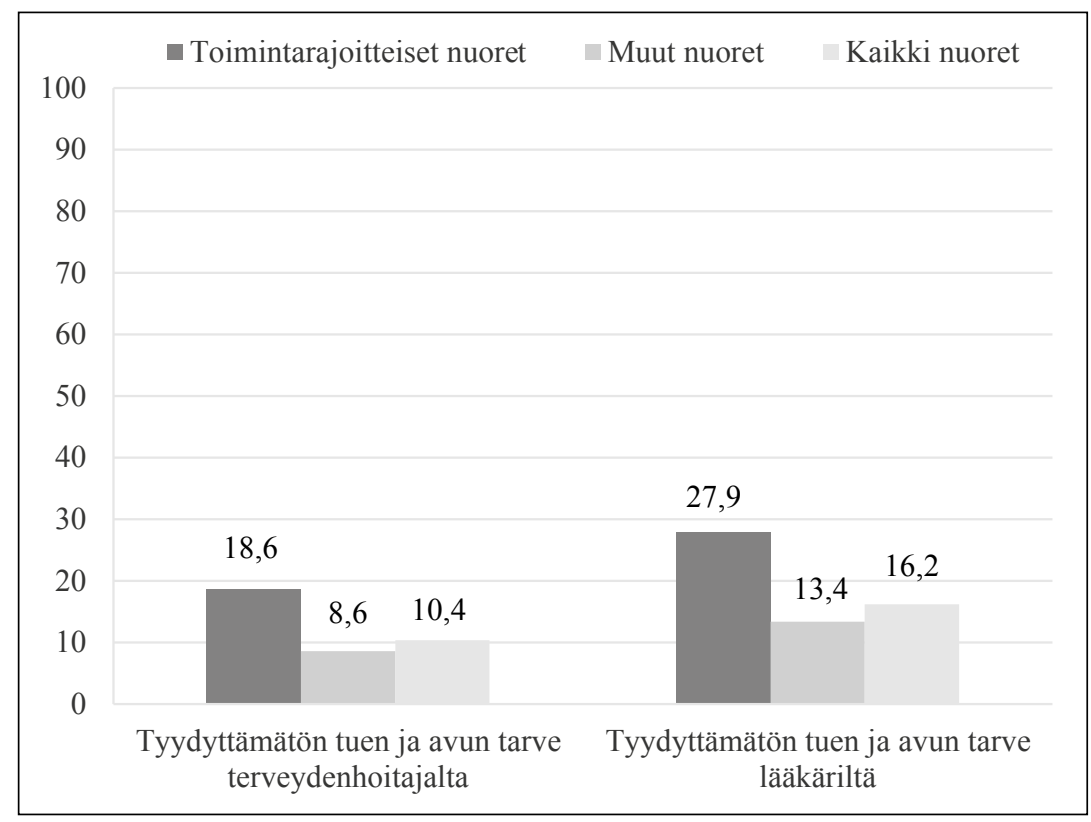

Kuvio 1. Nuorten tyydyttämätön tuen ja avun tarve toimintarajoitteisilla $(n=18964)$ ja muilla $(\mathrm{n}=113990)$ nuorilla (\%) tukea ja apua tarvinneista.

rissa oli enemmän kuin muissa nuorissa niitä, jotka olivat jääneet ilman tarvitsemaansa tukea ja apua $(9 \%$ vs. $3 \%, p<0,001)$. (Taulukko 2.)

Nuorista, jotka ilmoittivat tarvinneensa tukea ja apua terveydenhoitajalta, kymmenesosa ei ollut sitä saanut. Tämä tyydyttämätön tuen ja avun tarve oli yleisempää toimintarajoitteisilla nuorilla (19\%) kuin muilla nuorilla (9\%) $(\mathrm{p}<0,001)$. Lääkäriltä tukea ja apua tarvinneista nuorista noin joka kuudes ei ollut saanut sitä. Tyydyttämätön tuen ja avun tarve oli yli kaksi kertaa yleisempää toimintarajoitteisilla nuorilla $(28 \%)$ muihin nuoriin verrattuna $(13 \%)$ $(\mathrm{p}<0,001)$. (Kuvio 1.)

\section{TYYDYTTÄMÄTTÖMÄÄN TUEN JA AVUN TARPEESEEN YHTEYDESSÄ OLEVAT TEKIJÄT}

Sosiodemografiset tekijät olivat yhteydessä nuorten tyydyttämättömään tuen ja avun tarpeeseen (taulukko 1). Tytöillä oli poikia suurempi riski tyydyttämättömään tuen ja avun tarpeeseen sekä terveydenhoitajalta että lääkäriltä. Riski oli mui- 
Taulukko 3. Tyydyttämätön tuen ja avun tarve nuoren toimintarajoitteen mukaan (ristitulosuhde, OR ja 95 prosentin luottamusvälit, LV).

\begin{tabular}{|c|c|c|c|c|}
\hline \multirow[t]{3}{*}{ Regressiomallit } & \multicolumn{4}{|c|}{ Tyydyttämätön tuen ja avun tarve } \\
\hline & \multicolumn{2}{|c|}{ Terveydenhoitajalta } & \multicolumn{2}{|c|}{ Lääkäriltä } \\
\hline & OR & $95 \% \mathrm{LV}$ & OR & $95 \% \mathrm{LV}$ \\
\hline \multicolumn{5}{|l|}{ Toimintarajoite (ei) } \\
\hline Kyllä (vakioimaton) & 2,44 & $2,28-2,60$ & 2,50 & $2,33-2,69$ \\
\hline \multicolumn{5}{|l|}{ Toimintarajoite (ei) } \\
\hline Kyllä (vakioitu sukupuoli) & 2,37 & $2,21-2,53$ & 2,37 & $2,21-2,55$ \\
\hline \multicolumn{5}{|l|}{ Toimintarajoite (ei) } \\
\hline Kyllä (vakioitu sukupuoli ja kouluaste) & 2,36 & $2,21-2,53$ & 2,37 & $2,21-2,55$ \\
\hline \multicolumn{5}{|l|}{ Toimintarajoite (ei) } \\
\hline Kyllä (vakioitu sukupuoli ja syntyperä) & 2,33 & $2,18-2,50$ & 2,33 & $2,16-2,50$ \\
\hline \multicolumn{5}{|l|}{ Toimintarajoite (ei) } \\
\hline Kyllä (vakioitu sukupuoli ja äidin koulutus) & 2,33 & $2,17-2,50$ & 2,35 & $2,18-2,53$ \\
\hline \multicolumn{5}{|l|}{ Toimintarajoite (ei) } \\
\hline Kyllä (vakioitu sukupuoli ja perheen tal. til.) & 2,21 & $2,06-2,37$ & 2,19 & $2,04-2,36$ \\
\hline \multicolumn{5}{|l|}{ Toimintarajoite (ei) } \\
\hline Kyllä (vakioitu sosiodemografiset tekijät ${ }^{1}$ ) & 2,16 & $2,01-2,33$ & 2,15 & $1,99-2,32$ \\
\hline
\end{tabular}

Referenssiryhmä sulkeissa, ${ }^{1}$ sukupuoli, kouluaste, syntyperä, äidin koulutus ja perheen koettu taloudellinen tilanne

ta nuoria suurempi myös niillä nuorilla, joiden toinen vanhemmista oli ulkomaalaistaustainen tai nuori itse oli ulkomaalaistaustainen (syntynyt ulkomailla), nuoren äidillä oli enintään perusasteen koulutus, tai perheen taloudellinen tilanne koettiin huonoksi tai kohtalaiseksi. Kouluasteiden väliset erot tyydyttämättömässä tuen ja avun tarpeessa olivat vähäisiä.

Toimintarajoitteisilla nuorilla oli 2,5-kertainen riski tyydyttämättömään tuen ja avun tarpeeseen muihin nuoriin verrattuna tarkasteltaessa sekä terveydenhoitajalta että lääkäriltä saatua tukea ja apua koulu- ja opiskeluterveydenhuollosta. Sosiodemografisten tekijöiden huomioonottaminen regressiomalleissa vakioimalla eri tekijöitä pienensi toimintarajoitteen yhteyttä tyydyttämättömään tuen ja avun tarpeeseen, mutta vakioinninkin jälkeen erot olivat edelleen selvät. (Taulukko 3.)

\section{POHDINTA}

Tutkimus tuotti uutta väestötason tietoa nuorten tuen ja avun tarpeesta ja saannista terveydenhoitajalta ja lääkäriltä toimintarajoitteisilla ja muilla nuorilla sekä tyydyttämättömästä tuen ja avun tarpeesta sosiodemografisten tekijöiden mukaan. Tarkastelu tehtiin nuorten omasta näkökulmasta valtakunnallisen Kouluterveyskyselyn 2017 aineiston pohjalta.
Terveydenhoitajalta tukea ja apua tarvinneista nuorista kymmenesosa ei ollut saanut sitä, kun taas lääkäriltä tukea ja apua tarvinneista noin joka kuudes ei ollut sitä saanut. Tyydyttämätön tuen ja avun tarve oli yli kaksi kertaa yleisempää toimintarajoitteisilla nuorilla muihin nuoriin verrattuna. Sosiodemografisten tekijöiden vakioinnin jälkeenkin erot olivat selvät. Kanadassa toimintarajoitteisilla aikuisilla on todettu muuhun aikuisväestöön verrattuna yli kolminkertainen riski tyydyttämättömään terveyspalvelujen tarpeeseen ja erityisesti niillä, joilla on kipuihin, kuulovammaan ja tunne-elämän liittyviä toimintarajoitteita (25). Casey (2015) toteaa tutkimuksessaan toimintarajoitteisilla aikuisilla 2-3 kertaisen riskin tyydyttämättömään terveyspalvelujen tarpeeseen (29). Suomessa toimintarajoitteisilla aikuisilla on havaittu kaksinkertainen tyydyttämätön lääkärinhoidon tarve muuhun väestöön verrattuna (32). Tyydyttämätön terveyspalvelujen tarve näyttää pitkittäistutkimuksissa lisääntyvän ja erityisesti toimintarajoitteisilla $(27,29)$.

Tämän tutkimuksen tulosten kanssa samansuuntaisesti on useissa maissa todettu, että toimintarajoitteisten nuorten tarpeisiin ei ole pystytty vastaamaan riittävästi ja yhdenvertaisesti palveluissa $(9,11,13,14,33)$. Suomessa koulu- ja opiskeluterveydenhuollon palvelut ovat kaikille 
perusopetuksen ja toisen asteen koulutuksen opiskelijoille tarjolla olevia universaaleja palveluja. Esimerkiksi määräaikaiset terveystarkastukset on suunnattu kaikille toimintarajoitteista huolimatta. $(34,36$.) Kuitenkin palvelujen heikko koordinointi ja ammattilaisten puutteellinen osaaminen saattavat vaikuttaa toimintarajoitteisten lasten ja nuorten palvelujen laatuun, saatavuuteen ja riittävyyteen. Toimintarajoitteisten nuorten hyvinvoinnin turvaaminen kuuluu kaikille nuorten palveluissa toimiville, erityisesti peruspalveluihin ja arkisiin kasvuympäristöihin. Se ei ole ainoastaan erityispalvelujen tehtävä. Haasteita asettaa palvelujen integraatio perus- ja erityispalvelujen välillä. $(9,10$.)

Sosiodemografiset tekijät olivat yhteydessä tyydyttämättömään tuen ja avun tarpeeseen. Tytöillä oli poikia useammin tyydyttämätöntä tuen ja avun tarvetta koulu- ja opiskeluterveydenhuollosta. Tyydyttämätön terveyspalvelujen tarve on todettu olevan yleisempää naisilla kuin miehillä $(18,23,25-28)$. Opiskeluterveydenhuollosta nuoret naiset raportoivat tyydyttämätöntä palvelutarvetta noin kaksi kertaa useammin kuin miehet (20). Tämän tutkimuksen tuloksia tulkittaessa on hyvä ottaa huomioon, että tulokset perustuvat nuorten itsearvioon. Tytöt voivat olla poikia herkempiä raportoimaan tyydyttämättömästä tuen ja avun tarpeesta.

Tässä tutkimuksessa riski tyydyttämättömään tuen ja avun tarpeeseen oli muita nuoria suurempi myös niillä nuorilla, joiden toinen vanhemmista oli ulkomaalaistaustainen tai nuori itse oli ulkomaalaistaustainen (syntynyt ulkomailla), nuoren äidillä oli enintään perusasteen koulutus, tai perheen taloudellinen tilanne koettiin huonoksi tai kohtalaiseksi. Myös aikaisemmissa tutkimuksissa on havaittu tyydyttämättömän terveyspalvelujen tarpeen yhteys vähemmistöryhmiin kuulumiseen, alhaiseen koulutustasoon ja heikkoon taloudelliseen tilanteeseen $(18,23,25-28)$.

Sekä toimintarajoitteisten että muiden nuorten tyydyttämättömään tuen ja avun tarpeeseen saattavat vaikuttaa myös koulu- ja opiskeluterveydenhuollon käytettävissä olevat henkilöstövoimavarat. Esimerkiksi kouluterveydenhuollon palveluja on yhä paremmin käytettävissä, mutta niitä ei ole kaikissa kouluissa. Lukuvuonna 2014-2015 terveydenhoitajapalvelut olivat käytettävissä lähes jokaisessa (98-99 \%) koulussa ja lääkäripalvelut 87 prosentissa kouluista. Aluei- den ja koulujen välillä on selviä eroja, eikä alueellinen yhdenvertaisuus toteudu. (42.)

Tulosten perusteella suuri osa nuorista saa tukea ja apua koulu- ja opiskeluterveydenhuollosta, mutta on syytä olla huolissaan niistä nuorista, jotka kokevat riittämättömyyttä tuen ja avun saamisessa. Nuorten tyydyttämätön terveyspalvelujen tarve on yhteydessä terveyden kannalta kielteisiin seurauksiin, ja sen on todettu ennustavan huonoa terveyttä aikuisuudessa (28). Palvelujen käyttö muodostuu vuorovaikutuksessa ja kohtaamisissa palvelujärjestelmän ammattilaisten kanssa (20). Vaikka nuorilla olisi mahdollisuus käyttää terveyspalveluja, niin avun hakemiseen ja kokemuksiin palveluista vaikuttavat esimerkiksi leimautumisen pelko, huoli luottamuksellisuudesta ja tuomitsevista asenteista sekä ammattilaisten pätevyys, ystävällinen ja nuorta kunnioittava asenne, nuorten mahdollisuus osallistua ja palvelujen saatavuus (43).

Aikaisemmissa tutkimuksissa on tullut esille toimintarajoitteisten nuorten halu elää tavallista nuoren elämää ja tulla kohdatuksi palveluissa yksilöinä, joilla on tavalliset nuorten tarpeet ja toiveet esimerkiksi koulukäyntiin, opiskeluun ja vapaa-aikaan (44). Väestötutkimusten perusteella nuoret ovat varsin tyytyväisiä sosiaali- ja terveyspalveluihin. Kuitenkin kohtalaisen paljon tyydyttämätöntä palvelutarvetta kohdistuu terveyskeskuslääkärin ja sairaanhoitajan vastaanottoon sekä opiskeluterveydenhuoltoon. Näitä palveluja ilmoittaa saaneensa riittämättömästi vähintään joka kymmenes nuori. Lisäksi vaikka nuorille palvelua olisi saatavilla, se ei välttävättä ole kaikkien saavutettavissa tai sitä ei koeta sopivaksi omiin tarpeisiin. (20.)

Tutkimus perustuu valtakunnalliseen väestökyselyyn, joka järjestetään kouluissa ja oppilaitoksissa yhtenäisellä ohjeistuksella. Tulokset tarjoavat luotettavan kuvan nuorten kokemasta tuen ja avun saamisesta koulu- ja opiskeluterveydenhuollosta. Kouluterveyskyselyn aineisto on kerätty kokonaistutkimuksena. Tutkimuksessa on käytetty luotettaviksi todettuja mittareita tai mittarit on kehitetty asiantuntijaryhmissä, esitestattu ja todettu toimiviksi. (37.)

Tutkimuksessa ei ollut mukana selkokielisiin lomakkeisiin vastanneita nuoria, joten todennäköisesti vakavia toimintarajoitteita kokevia nuoria on maassa tässä esitettyä enemmän. Selkokielisiin lomakkeisiin vastanneilla nuorilla on 
todennäköisesti erilaisia tuen ja avun tarpeita koulu- ja opiskeluterveydenhuollosta kuin muilla nuorilla, ja todennäköisesti eroja on myös kokemuksissa tuen ja avun saamisesta. Erityisluokkien, peruskouluasteen erityiskoulujen ja ammatillisten erityisoppilaitosten on ollut mahdollista osallistua kyselyyn, mikäli opiskelijat kykenevät vastaamaan itsenäisesti. Näiden luokkien, koulujen ja oppilaitosten osallistumisaktiivisuudesta kouluterveyskyselyyn ei ole tarkkaa tietoa. (37.) Tulokset perustuvat nuorten subjektiivisiin arvioihin, mikä on saattanut tuottaa sosiaalisesti toivottavia vastauksia. Toisaalta nuoren kokemusta omasta palveluntarpeesta ja sen tyydyttymisestä ei voida yksilöstä riippumatta arvioida (23).

Tässä tutkimuksessa tyydyttämättömän tuen ja avun tarpeen mittarina käytettiin yhteen kysymykseen perustuvaa nuoren itsearviota. Samankaltaista menetelmää on käytetty sekä kotimaisissa että kansainvälisissä tutkimuksissa, joissa palveluntarvetta on arvioitu asiakkaille itselleen osoitetuilla suorilla kysymyksillä $(18,23,28)$. Tyydyttämätön tuen ja avun tarve on kuitenkin vaikeasti mitattava käsite, ja nuorilla voi olla hyvin erilaisia tuen ja avun tarpeita omaan hyvinvointiinsa koulu- ja opiskeluterveydenhuollosta. Tutkimuksessa käytetyllä mittarilla ei saada kuvaa niistä nuorista, jotka ovat saaneet tukea ja apua, mutta se on ollut riittämätöntä heidän tarpeisiinsa nähden. Tästä johtuen tutkimuksessa todettu tyydyttämätön tuen ja avun tarve on todennäköisesti aliarvioitu.

Tutkimuksessa tarkasteltiin toimintarajoitteita kokevia nuoria yhtenä ryhmänä riippumatta siitä, millä toimintakyvyn ulottuvuudella rajoite oli. Toimintarajoitteiset nuoret eivät kuitenkaan ole yhtenäinen ryhmä. Jatkossa on tärkeää syventää tarkastelua eri toimintarajoiteryhmiin, kuten kognitiivisia toimintarajoitteita kokeviin (45). Esimerkiksi nuorten erilaisten toimintarajoitteiden tarkastelu sukupuolen ja kouluasteen mukaan osoittaa, että ammatillisissa oppilaitoksissa opiskelevista tytöistä suurempi osa kuin lukiolaistytöistä raportoi muistamiseen liittyvistä vaikeuksista (15). Näiden nuorten tuen ja avun tarve on hyvin erilaista kuin esimerkiksi näkö- tai kuulovaikeuksia kokevien nuorten. Tutkimustietoa tarvitaan palvelujärjestelmän toimivuudesta ja tarpeisiin vastaavuudesta sekä palvelujen saatavuudesta, saavutettavuudesta, hyväksyttävyydestä, laadusta ja vaikuttavuudesta nuorten kokemana (20). Lisäksi tarvitaan väestötason seurantatietoa toimintarajoitteisten lasten ja nuorten hyvinvoinnista, terveydestä ja palveluista, joka on myös kansainvälisesti vertailukelpoista. $(9,10$.)

\section{JOHTOPÄÄTÖKSET}

Tutkimuksen tulokset viittaavat siihen, että toimintarajoite on tärkeä nuorten tyydyttämättömään palvelutarpeeseen yhteydessä oleva tekijä koulu-ja opiskeluterveydenhuollossa. Nuoren itsearvioima toimintarajoite on yhteydessä hyvinvointiin liittyvään tyydyttämättömään tuen ja avun tarpeeseen sekä terveydenhoitajalta että lääkäriltä. Toimintarajoitteisilla nuorilla on muita nuoria enemmän erilaisia hyvinvointiin ja terveyteen liittyviä haasteita. Osa näistä tuen ja avun tarpeista saattaa jäädä tunnistamatta, jolloin nuori kokee jäävänsä ilman tarvitsemaansa tukea ja apua. Erot toimintarajoitteisten nuorten ja muiden nuorten välillä ovat merkittäviä, mikä on haaste yhdenvertaisuuden toteutumiselle. Universaaleina palveluina koulu- ja opiskeluterveydenhuollolla on keskeinen rooli näiden hyvinvointierojen kaventamisessa ja yhdenvertaisuuden edistämisessä.

Palvelutarpeisiin vastaamista ja yhdenvertaisuuden toteutumista voidaan edistää tunnistamalla aikaisempaa varhaisemmassa vaiheessa toimintarajoitteisten nuorten tuen ja avun tarpeita. Toimintarajoitteisten nuorten hyvinvoinnin turvaaminen ja edistäminen kuuluvat kaikille nuorten palveluissa toimiville palvelujärjestelmän eri tasoilla. Nuorten hyvinvointia voidaan tukea kouluissa ja oppilaitoksissa esimerkiksi lisäämällä edelleen osallisuutta ja yhteisöllisyyttä, huolehtimalla avun yhdenvertaisesta saatavuudesta sekä kohtaamalla nuori yksilönä, tavallisena nuorena ja vahvistamalla nuoren voimavaroja.

\section{KIRJOITTAIIEN KONTRIBUUTIOT:}

Kanste osallistui tutkimusaineiston hankintaan ja tutkimuksen suunnitteluun sekä vastasi käsikirjoituksen kirjoittamisesta ja tilastollisten analyysien tekemisestä.

Halme vastasi tutkimusaineiston hankinnasta sekä osallistui tutkimuksen suunnitteluun ja antoi kriittisiä ehdotuksia kirjoittamisprosessin aikana.

Sainio osallistui tutkimuksen suunnitteluun ja antoi kriittisiä ehdotuksia kirjoittamisprosessin aikana. 
International conventions on rights of children and persons with disabilities oblige signatory countries to improve the equality of access to services for young people with disabilities by removing obstacles and providing appropriate support. Thus, the study examined needs for, and accessibility of, support and assistance from school health nurse and physician among young people with and without disabilities, particularly unmet needs for support and assistance in relation to sociodemographic factors. The study was based on data from the nationwide School Health Promotion study 2017 (n=138 972), which were analyzed by cross-tabulation, chi-square tests and logistic regression analysis. Approximately $14 \%$ of the young people reported that they had some serious disability, e.g. a difficulty in seeing, hearing, walking, remembering, learning or concentrating. However, $10 \%$ of those reporting a need for support and assistance from a school health nurse had not received it. Unmet needs for support and assistance were more common among youths with disabilities (19\%) than other youths $(9 \%)$. Moreover, $16 \%$ of young people who needed support and assistance from physi- cian had not received it. Unmet needs for support and assistance were more than twice as common among young people with disabilities $(28 \%)$ than among other young people (13\%). Young people with disabilities had more than two-fold higher risks of unmet needs for support and assistance than other young people, from both school health nurse and physician, after controlling for sociodemographic factors. In conclusion, disabled young people have more well-being and health-related support needs than others, some of which may be unidentified, and young people may not receive required support and assistance. There are challenging differences in these respects between young people with and without disabilities. School and student health services can play key roles in reducing these differences in well-being, thereby promoting equality.

Keywords: school and student health services, youth, disabilities, unmet needs for support and assistance.

Saapunut 22.06.2018

Hyväksytty 17.09.2018

\section{LÄHTEET}

(1) Convention on the Rights of the Child, CRC. 1989. Luettu 3.5.2018. https://www.unicef.org/crc/

(2) Convention on the Rights of Persons with Disabilities, CRPD. 2006. Luettu 3.5.2018. http://www.un.org/disabilities/documents/ convention/convention_accessible_pdf.pdf

(3) Vammaissopimus 2016. SopS 26-27/2016. Yleissopimus vammaisten henkilöiden oikeuksista ja sen lisäpöytäkirja. Luettu 3.5.2018. https://www.finlex.fi/fi/sopimukset/ sopsviite/2016/20160027

(4) Nurmi-Koikkalainen P. 2017. Tiedontarve vammaisuudesta. Teoksessa: NurmiKoikkalainen P ym. (toim.) Tietoa ja tietotarpeita vammaisuudesta: Analyysia THL:n tietotuotannosta. Työpaperi 38/2017, THL, Helsinki, s. 13-19.

(5) Berger N, Robine J-M, Ojima T, ym. Harmonising summary measures of population health using global survey instruments. J Epidemiol Community Health 2016;70:1039_ 1044. doi: 10.1136/jech-2015-206870

(6) WG. 2017. Washington Group on Disability Statistics. Luettu 3.5.2018. http://www. washingtongroup-disability.com/

(7) Sainio P, Koskinen S. 2017. Toimintarajoitteiden mittaaminen väestötutkimuksissa. Teoksessa: Nurmi-Koikkalainen P ym. (toim.) Tietoa ja tietotarpeita vammaisuudesta: Analyysia THL:n tietotuotannosta. Työpaperi 38/2017, THL, Helsinki, s. 29-31.

(8) International Classification of Functioning, Disability and Health (ICF). Geneva, World Health Organization, 2001. Luettu 3.5.2018. http://www.who.int/classifications/icf/en/

(9) WHO 2011. World report on disability. World Health Organization and the World Bank. Luettu 3.5.2018. http://www.who.int/ disabilities/world_report/2011/report.pdf?ua $=1$

(10) WHO 2015. WHO global disability action plan 2014-2021. Better health for all people with disability. Luettu 3.5.2018. http://apps.who.int/ iris/bitstream/10665/199544/1/9789241509619 eng.pdf?ua $=1$ 
(11) Groce NE, Kett M. 2014. Youth with Disabilities. Working Paper Series: No. 23. Leonard Cheshire Disability and Inclusive Development Centre, University College London.

(12) Mitra S, Posarac A, Vick, B. Disability and poverty in developing countries: a multidimensional study. World Development 2013;41:1-18. doi.org/10.1016/j.worlddev.2012.05.024

(13) Stokes H, Turnbull M, Wyn J. 2013. Young People with a Disability: Independence and Opportunity. A Literature Review. Research Report 39. Youth Research Centre, University of Melbourne.

(14) UNICEF 2013. Children and Young People with Disabilities. Fact Sheet. May 2013. Luettu 3.5.2018. https://www.unicef.org/disabilities/ files/Factsheet_A5_Web_NEW.pdf

(15) Kanste O, Sainio P, Halme N, ym. 2017. Toimintarajoitteisten nuorten hyvinvointi ja avun saaminen - Toteutuuko yhdenvertaisuus? Kouluterveyskyselyn tuloksia. Tutkimuksesta tiiviisti 24, elokuu 2017. THL, Helsinki. http://urn.fi/URN:ISBN:978-952-302-838-8

(16) Suarez-Balcazar Y, Agudelo Orozco A, Mate M, ym. Unpacking barriers to healthy lifestyles from the perspective of youth with disabilities and their parents.

J Prev Interv Community 2018;46:61-72. doi: 10.1080/10852352.2018.1386270

(17) Berg KL, Shiu CS, Msall ME, ym. Victimization and depression among youth with disabilities in the US child welfare system. Child Care Health Dev 2015;41:989-999. doi: $10.1111 /$ cch.12233

(18) Fjær EL, Stornes P, Borisova LV, ym. Subjective perceptions of unmet need for health care in Europe among social groups: Findings from the European social survey (2014) special module on the social determinants of health. Eur J Public Health 2017;27:82-89. doi: 10.1093/eurpub/ckw219.

(19) Levesque J-F, Harris MF, Russell G. Patientcentred access to health care: conceptualising access at the interface of health systems and populations. Int J Equity Health 2013;12:18. doi: 10.1186/1475-9276-12-18

(20) Karvonen S, Kestilä L, Kauppinen TM. (2017) Kokevatko nuoret saavansa tarvitsemiansa sosiaali- ja terveyspalveluja? Tuloksia väestötutkimuksista. Teoksessa: Aaltonen S, Kivijärvi A. (toim.) Nuoret aikuiset hyvinvointipalvelujen käyttäjinä ja kohteina. Nuorisotutkimusverkosto ja Nuorisotutkimusseura, Helsinki, s. 27-52.

(21) Aday LA, Andersen R. A framework for the study of access to medical care. Health Serv Res 1974;9:208-220.

(22) Andersen R. Revisiting the behavioral model and access to medical care: does it matter? J Health Soc Behav 1995;36:1-10. doi: $10.2307 / 2137284$
(23) Manderbacka K, Muuri A, Keskimäki I, ym. Mitä tyydyttämätön palvelutarve kertoo terveyspalvelujen saatavuudesta? Sosiaalilääk Aikak 2012;49:4-12.

(24) Allin S, Grignon M, Le Grand J. Subjective unmet need and utilization of health care services in Canada: what are the equity implications? Soc Sci Med 2010;70:465-472. doi: 10.1016/j.socscimed.2009.10.027

(25) McColl MA, Jarzynowska A, Shortt SED. Unmet health care needs of people with disabilities: population level evidence. Disability \& Society 2010:25;205-218. doi.org/10.1080/09687590903537406

(26) Hwang B, Chun S-M, Park J-H, ym. Unmet healthcare needs in people with disabilities: comparison with the general population in Korea. Ann Rehabil Med 2011;35:627-635. doi: 10.5535/arm.2011.35.5.627.

(27) Mahmoudi E, Meade MA. Disparities in access to health care among adults with physical disabilities: analysis of a representative national sample for a ten-year period. Disabil Health J 2015;8:182-190. doi: 10.1016/j.dhjo.2014.08.007.

(28) Hargreaves DS, Elliott MN, Viner RM, ym. Unmet health care need in US adolescents and adult health outcomes. Pediatrics 2015;136:513-520. doi:10.1542/peds.2015-0237

(29) Casey R. Disability and unmet health care needs in Canada: A longitudinal analysis. Disabil Health J 2015:8;173-181. doi.org/10.1016/j.dhjo.2014.09.010

(30) Mikkola T, Polku H, Sainio P, ym. Hearing loss and use of health services: a populationbased cross-sectional study among Finnish older adults. BMC Geriatrics 2016;16:182. doi:10.1186/s12877-016-0356-5

(31) Sakellariou D, Rotarou ES. Access to healthcare for men and women with disabilities in the UK: secondary analysis of cross-sectional data. BMJ Open 2017;7:e016614. doi: 10.1136/bmjopen-2017-016614

(32) Sainio P, Sääksjärvi K, Nurmi-Koikkalainen P, ym. 2017. Toimintarajoitteisuuden yleisyys ja toimintarajoitteisten henkilöiden hyvinvointi - tuloksia Terveys 2011 -tutkimuksesta.

Teoksessa: Nurmi-Koikkalainen P ym. (toim.) Tietoa ja tietotarpeita vammaisuudesta: Analyysia THL:n tietotuotannosta. Työpaperi 38/2017, THL, Helsinki, s. 34-52.

(33) Tan SH. Unmet health care service needs of children with disabilities in Penang, Malaysia. Asia Pac J Public Health 2015;27:41S-51S. doi: $10.1177 / 1010539515592461$

(34) Oppilas- ja opiskeluhuoltolaki 1287/2013. Luettu 3.5.2018. https://www.finlex.fi/fi/laki/ alkup/2013/20131287

(35) Terveydenhuoltolaki 1326/2010. Luettu 3.5.2018. https://www.finlex.fi/fi/laki/ ajantasa/2010/20101326 
(36) Valtioneuvoston asetus neuvolatoiminnasta, koulu- ja opiskeluterveydenhuollosta sekä lasten ja nuorten ehkäisevästä suun terveydenhuollosta 338/2011. Luettu 3.5.2018. https://www.finlex. fi/fi/laki/alkup/2011/20110338

(37) Kouluterveyskysely (2017) Terveyden ja hyvinvoinnin laitos. Luettu 3.5.2018. https:// www.thl.fi/fi/tutkimus-ja-asiantuntijatyo/ vaestotutkimukset/kouluterveyskysely

(38) Robinson-Cimpian JP. Inaccurate estimation of disparities due to mischievous responders: several suggestions to assess conclusions. Educational Researcher 2014:43;171-185. doi: 10.3102/0013189X14534297

(39) TENK. 2012. Hyvä tieteellinen käytäntö ja sen loukkausepäilyjen käsitteleminen Suomessa. Luettu 3.5.2018. http://www.tenk.fi/fi/htk-ohje

(40) Grove SK. 2007. Statistics for Health Care Research: A Practical Workbook. Saunders, USA.

(41) Hosmer DW \& Lemeshow S. 1989. Applied logistic regression. John Wiley \& Sons, Inc, USA.

(42) Wiss K, Ståhl T, Saaristo V, ym. Terveydenhoitajat, lääkärit, psykologit ja kuraattorit peruskouluissa 2008-2015. Suomen Lääkärilehti 2017:72;127-135.

(43) Ambresin AE, Bennett K, Patton GC, $\mathrm{ym}$. Assessment of youth-friendly health care: a systematic review of indicators drawn from young people's perspectives. J Adolesc Health 2013;52:670-681. doi: 10.1016/j.jadohealth.2012.12.014.
(44) Peltola M, Moisio J. 2017. Ääniä ja äänettömyyttä palvelukentillä. Katsaus lasten ja nuorten palvelukokemuksia koskevaan tietoon. Nuorisotutkimusverkosto/ Nuorisotutkimusseura. Verkkojulkaisuja 112. STM, Helsinki. Luettu 3.5.2018. http://www. nuorisotutkimusseura.fi/images/julkaisuja/ aania_ja_aanettomyytta_palvelukentilla.pdf

(45) Rowland M, Peterson-Besse J, Dobbertin K, ym. Health outcome disparities among subgroups of people with disabilities: a scoping review. Disabil Health J 2014;7:136-150. doi: 10.1016/j.dhjo.2013.09.003.

\section{Outi Kanste}

TtT, dosentti, yliopistonlehtori

Hoitotieteen ja terveyshallintotieteen tutkimusyksikkö

Oulun yliopisto

Nina Halme

$T t T$, erikoistutkija

Lapset, nuoret ja perheet -yksikkö

Terveyden ja hyvinvoinnin laitos

\section{PäIVI SAINIO}

THM, kehittämispäällikkö

Iäkkäät, vammaiset ja toimintakyky -yksikkö Terveyden ja byvinvoinnin laitos 